\title{
MANASSEH AND THE PUNISHMENT NARRATIVE ${ }^{1}$
}

\author{
Andrew Taehang Ohm
}

\begin{abstract}
Summary
This paper examines the nature of the Manasseh account (2 Kgs 21:118) in the macrostructure of the Deuteronomistic literature, especially the books of Samuel and Kings, in which remarkably similar narrative schemes are embedded. They consist of 'sin description', 'sin development', 'reminder', 'response', and 'punishment'. I call this unique literary genre 'punishment narrative'. In the punishment itself several distinctive common devices (destruction of a cultic place, end of family/dynasty line, and a death of an innocent family group member) are employed to show a fulfilment of prophecy. A number of allusions and similarities between the death of Saul and the anonymous prophet in 1 Kings 13 and between the death of Abijah, Jeroboam's son (1 Kgs 14:1-18) and Josiah (2 Kgs 23:28-30) are discussed as well. Thereby I put the Manasseh narrative in this category. A close reading shows that the Manasseh and Josiah narratives are not independent but, in effect, two different parts of one punishment narrative. This paper also suggests that these punishment narratives overarch one another in Samuel-Kings from the beginning to the end. Finally, it concludes that the work of Samuel-Kings was woven with different materials but woven into one narrative thread.
\end{abstract}

\section{Introduction}

As far as its literary formation is concerned the Manasseh narrative engenders many problems. Reading through the Manasseh narrative the

1 A part of this paper was read at the Historical Section of the Society of Biblical Literature International Meeting in Edinburgh on 2-6 July, 2006. 
reader encounters the accusation against Manasseh and the people of Judah. It seems that the anger of the Deity would immediately take revenge on all sinners and the betrayers of the covenant, who had defiled the holy place. However, unexpectedly, the urgency fades away and Amon's brief account continues. The doom prophecy of 2 Kings 31:10-15 was not, in fact, fulfilled within the periphery of Manasseh's narrative. No resolution of the issue, nor any just punishment takes place. $^{2}$ To make matters worse, the unusually long reign of Manasseh makes things more complicated. This causes many questions not only about the text but also about the Deuteronomistic theology itself. The description in Deuteronomy 7:10 $0^{3}$ looks self-contradictory when we see it in the same ideological sphere. It reasons that Yahweh is never slow when he decides to reward Manasseh. Considering this tension, Noth's thesis which claims that the work of DtrH is a whole looks unwarranted. In the latter part, in the account of the death of Josiah

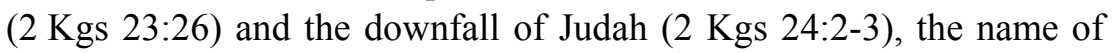
Manasseh and his connection is mentioned. However, this loose literary installation to connect Manasseh and Josiah does not look strong enough to justify such prominent discrepancies. Why then did Manasseh, who was the figure most responsible for the nation's catastrophe, escape punishment? Why did the innocent Josiah have to be killed because of his grandfather's sin? Was the author (or the redactor) not concerned about the cohesion of the narrative, leaving his work as a mixture of different historical materials? This phenomenon has led to much debate and various suggestions. ${ }^{4}$ Some scholars have

2 Normally a narrative consists of beginning, development, climax, and resolution. Yet the Manasseh narrative lacks proper resolution.

3 'and requites to their face those who hate him, by destroying them; he will not be slack with him who hates him, he will requite him to his face' (RSV). Hereafter the English translations of the Hebrew Bible are taken from the RSV.

4 Von Rad sought for a possible solution in the explanation of the historical materials the Deuteronomist used. 'On the other hand one must bear in mind that from a literary point of view the Deuteronomist is working almost exclusively with traditional material, which does not always readily accommodate itself to his basic theological attitude.' Gerhard von Rad, The Problem of the Hexateuch and Other Essays (London: SCM, 1984): 212. By the same logic he also said, 'the undeuteronomistic and highly picturesque language, as well as the poetic form are preserved' in $1 \mathrm{Kgs}$ 14:10, 15; 16:4; 2 Kgs 21:13 (Problem of the Hexateuch, 212). Cross contended for a two redactional model in the redaction of the history: Dtr1 and Dtr2. The first was composed as Josianic progaganda while the other was edited by a second hand in the post-exilic period. Frank Moore Cross, Canaanite Myth and Hebrew Epic: Essays in the History of the Religion of Israel (Cambridge, MA: Harvard University Press, 1973): 287-289. The Göttingen school has suggested 'DtrG', 'DtrN', and 'DtrP'. 
discovered some fragmentary affinities between the Manasseh texts and other texts such as Eli, Jeroboam and Josiah. However, they have many limitations in their explanation of the Dtr's distinctive literary scheme, which binds all these texts together revealing its theological perspective. $^{5}$

\section{Punishment Narrative}

Thus it is crucial to examine the narrative devices lurking in SamuelKings. Above all I would suggest that the Manasseh narrative is not an

Rudolf Smend, 'Das Gesetz und die Völker: Ein Beitrag zur deuteronomistischen Redaktionsgeschichte' in Probleme Biblischer Theologie (Munich: Kaiser, 1971): 494509; Walter Dietrich, Prophetie und Geschichte: Eine redaktionsgeschichtliche Untersuchung (Göttingen: Vandenhoeck \& Ruprecht, 1972); Timo Veijola, Das Königtum in der Beurteilung der deuteronomistischen Historiographie: Eine redaktionsgeschichtliche Untersuchung (Helsinki: Suomalainen Tiedeakatemia, 1977): 147. For more recent references on this issue, see Claus Westermann, Die Geschichtsbücher des Alten Testaments: Gab es ein deuteronomistisches Geschichtswerk? (Gutersloh: Kaiser, 1994); Baruch Halpern and David S. Vanderhooft, 'The Editions of Kings in the 7th-6th Centuries BC', HUCA (1991): 179244; A compromise or alteration in both schools' positions was made by Erik Eynikel, The Reform of King Josiah and the Composition of the Deuteronomistic History (Leiden: E. J. Brill, 1996): 112-14; Erik Eynikel, 'The Portrait of Manasseh and the Deuteronomistic History' in Deuteronomy and Deuteronomic Literature (Leuven: Peeters, 1997): 233-66; Marvin A. Sweeney, King Josiah of Judah: The Lost Messiah of Israel (Oxford: Oxford University Press, 2001).

5 Lasine pointed out the difficulty in finding a literary resemblance between the Manasseh text and the texts on Hezekiah and Ahab, which appear in 2 Kgs 21:3. Rather, he finds much closer parallels in the texts of Jeroboam: 1) they are responsible for the downfall of their respective kingdoms; 2) they commonly led their people into sin. Stuart Lasine, 'Manasseh as Villain and Scapegoat' in New Literary Criticism and the Hebrew Bible (Sheffield: JSOT Press, 1993): 164-65. Auld has pointed out some common themes between the text of Eli (1 Sam. 3) and the Manasseh text (2 Kgs 21:12). Following Fokkelman's suggestion he claims that 1 Sam. 3 was presented 'to restate and radicalise the divine threat already pronounced against Eli by the man of God (1 Sam. 2:27-36): the man of God had said only that a new and sure priestly house would replace Eli's'. Auld, 'From King to Prophet in Samuel and Kings', 44 = Auld, 'Samuel at the Threshold: Selected Works of Graeme Auld', 184. There Auld finally concludes, "the death of Eli and his sons prefigures the end of the house of Saul in favour of a new and different order'. Cf. J. P. Fokkelman, Narrative Art and Poetry in the Books of Samuel: A Full Interpretation Based on Stylistic and Structural Analyses (Vol. 4; Assen: Van Gorcum, 1993): 181-93. Eynikel saw Manasseh as the character for 'contra-reform' of Josiah claiming that the narrative of the reform of king Josiah ( 2 Kgs 23 ) is implicitly parallel to the Manasseh narrative. Erik Eynikel, 'The Portrait of Manasseh and the Deuteronomistic History', 234. However, all these approaches have limitations which lack Dtr's profound punishment narrative scheme embedded in these texts. 
independent episode but the beginning of an extensive punishment narrative. ${ }^{6}$

I would call the Manasseh narrative a punishment narrative which exhibits Yahweh's intervention to punish a man's particular transgressions, putting an end to a person's destiny including the dynasty as a way of Yahweh's judgement. The punishment narrative should be distinguished from a common 'tragedy' that focuses on the rise and fall of a great hero's life. ${ }^{7}$ The punishment narrative is restricted within the range of DtrH describing Israel's history in its Deuteronomistic ideology employing its own distinctive narrative schemes. ${ }^{8}$ These narratives occur regularly as a sign of the turning of an era. Accordingly, Eli's, Saul's, Jeroboam's and Manasseh's narratives can be placed in the same category. Eli's punishment appears as the prelude to Samuel-Kings. Saul's punishment narrative occurs when the Benjamite dynasty ends and the new Davidic dynasty is forging ahead. Jeroboam's punishment narrative intervenes when the northern kingdom arises. Hence, it is not strange that Manasseh's punishment narrative is located at the conclusion of Samuel-Kings (or at the end of DtrH) concluding Israel's long monarchic period. ${ }^{9}$ Along with each punishment narrative we can easily discover the homogenous repetition of particular plots. The sequence of those plots is not always identical. But it is impossible to complete a punishment narrative without any of these common instruments as follows.

6 Thus van Keulen's analysis based on the method of Licht has the limitation of not seeing the whole picture of the Samuel-Kings' narrative. P. S. F. van Keulen, Manasseh through the Eyes of the Deuteronomists: The Manasseh Account (2 Kings 21:1-18) and the Final Chapters of the Deuteronomistic History (Leiden: Brill, 1996): 65-68.

7 Mary E. Mills, Historical Israel, Biblical Israel: Joshua to 2 Kings (London: Cassell, 1999): 72. Cf. Exum regards Saul's story in 1 Sam. 9-31 as a tragic narrative. J. Cheryl Exum, Tragedy and Biblical Narrative (Cambridge: Cambridge University Press, 1992): 16-44.

8 From DtrH we find a different concept as in the statement of Abraham to the angels who were going to destroy the cities of Sodom and Gomorrah. He says, 'Would you also destroy the righteous with the wicked?' (Gen. 18:23). And this Deuteronomistic theology with the punishment of a just one on account of a wicked one can be found in Exod. 34:7 outside of DtrH. However, it is not strange when this part of the Sinai pericope is taken from 'the D-version' by the writer P. William Johnstone, 'The Chronicles Analogy in Pentateuchal Studies' in Chronicles and Exodus: An Analogy and Its Application (Sheffield: Sheffield Academic Press, 1998): 156-57.

9 This type of punishment narrative appears more clearly in Kings as seen in the death of Jeroboam's son and Josiah. 


\subsection{Sin Description}

A story usually begins with a character evaluation. An important member of a group (family/dynasty/nation) commits serious sins specially related to a religious taboo which is strictly prohibited in advance by the law or a special cultic admonition.

\subsection{Sin Development}

The person commits sins repeatedly without any hope of restoration. $\mathrm{He}$ aggravates his sins by further misconduct. Yet, due punishment does not fall immediately. It is delayed.

\subsection{Reminder/Prophetic Intervention}

In this stage a narrative is interrupted by a prophetic voice reminding people of the law and the covenant. The message is given by a prophet or a prophetic voice. It reminds the sinner of his election and his family/dynasty and the importance of the chosen cultic place. Sometimes this prophecy is given by many voices and recurs before the punishment is given at the final stage. The sinner who violates the taboo is judged for his evil deeds with a reminder of the law and the covenant. It reveals the mercy of Yahweh who had chosen him/the tribe/the nation or the cultic place. As indicated by Noth, this is an important concept in the Deuteronomistic narratives and Deuteronomic law (Deut. 7:2;14:2). ${ }^{10}$

\subsection{Response/Climax}

The sinner is now confronted with the final stage. A climax is a conceptional turning point where the character confronts his fate whether he repents or refuses to do so. ${ }^{11}$ In most cases a sinner ignores this last chance and worsens his behaviour. Rarely does someone show a temporary conversion like Saul or Ahab (1 Sam. 15:25; 30-31; $1 \mathrm{Kgs}$ 21:27-29). However, as for Ahab the punishment once delivered never expires but is transmitted to the next generation. This is also one of the essential ideological pillars sustaining DtrH. ${ }^{12}$ One of the significant word indicators at this step is the appearance of the root of שמעע 'to

10 Martin Noth, The Deuteronomistic History (Sheffield: JSOT Press, 1981): 90.

11 At this stage the main character reaches 'the apex of his/her fortune'. Jean Louis Ska, Our Fathers Have Told Us: Introduction to the Analysis of Hebrew Narratives (Roma: Editrice Pontificio Istituto Biblico, 1990): 27.

12 David's sin was not pardoned easily but his baby son born from Bathsheba had to die (2 Sam. 12:18), Solomon's sins influenced the division of the kingdom (1 Kgs 11:32-36) and Hezekiah's sin affected the next generation (2 Kgs 20:17-19) and so on. 
listen' used as an instrument to call for a character's response to the warning. Here the Deity usually uses prophets to deliver his judgement. In some cases others perform prophetic roles delivering Yahweh's message. ${ }^{13}$ The prophetic voice is essential at this stage.

\subsection{Punishment}

At this final moment, the due punishment falls. A recent study of the theme of divine anger explains the important categories when the anger of the gods appears in ancient Near Eastern documents. Berges summarises four important categories: 'a) the anger that seeks to destroy mankind; b) the anger that intervenes in the destiny of the people; c) the anger that destroys temple cities with their sanctuaries; d) the anger that brings the individual into the danger of death'. ${ }^{14}$ All these elements appear in the punishment narratives. But the DtrH punishment narratives look more dramatised and, using cohesive devices and schemes such as prophetic voices and theological comments reminding men of the law and the covenant, are quite distinct from other ancient Near Eastern documents. Now the sinner inevitably progresses to his fate. ${ }^{15}$ As instruments of punishment the Deity uses various disasters such as war, ${ }^{16}$ disease, or the loss of a close family member. Through this process the sinner or his family members are to be annihilated. The death of an innocent human being is involved in the punishment. In most cases at the conclusion an innocent family member is to die because of the main character's sins. Yet, the sinner himself sometimes cannot see the whole range of the punishment. However, the reader can watch all the elements of the events which accomplish the prediction. Throughout Samuel-Kings these particular punishment narrative schemes are linked closely. ${ }^{17}$ As a literary

13 Interestingly Samuel delivered a judgement message not only before he became a prophet (1 Sam. 3:11-14) but also after he died (1 Sam. 28:15-19). Eli's daughter-inlaw also delivered a prophetic message. But her statement was given as a concluding comment not to call for repentance (1 Sam. 4:19-21).

14 Ulrich Berges, 'Der Zorn Gottes in der Prophetie und Poesie Israels auf dem Hintergrund altorientalischer Vorstellungen', Biblica 85 (2004): 330.

15 Like Eli's two sons, and Saul (1 Sam. 4:1-11; cf. 1 Kgs 14:17; 2 Kgs 23:29-30).

16 See also Richard G. Bowman, 'Narrative Criticism of Judges: Human Purpose in Conflict with Divine Presence' in Judges and Method, ed. Gale A. Yee (Minneapolis: Fortress, 1995): 32.

17 An exceptional case of punishment which appears out of Dtr is the narrative of Baal Peor in Num. 25:1-9. Exactly the same Dtr theology is found in Deut. 4:3 and Josh. 22:17-20. According to Noth this Baal Peor narrative is inserted after the completion of the Pentateuch by a later hand. Martin Noth, A History of Pentateuchal 
stratagem these narrative schemes could be extended or modified in order. But these five narrative factors are indispensable to further the resolution of the punishment narrative as follows:

Sin Description $\rightarrow$ Sin Development $\rightarrow$ Prophetic Intervention
$\rightarrow$ Response $\rightarrow$ Punishment

These punishment narratives occur at critical moments in Israel's history. ${ }^{18}$ These literary instruments are so closely connected that it is difficult to regard them as a coincidence.

\section{Punishment Narratives}

\subsection{Eli's Punishment Narrative (1 Sam. 2:1-4:22): the First Destruction of a National Cultic Place}

\section{(i) Sin Description}

The narrative begins with an evaluation of Eli's sons portraying them as villains (1 Sam. 2:12). They defile the holy place in Shiloh by polluting sacrifices.

\section{(ii) Development of Sins}

There is no sign that any of Eli's wicked sons would change their behaviour. Their studied ignorance of Yahweh defiled the holy sacrifices. This was tantamount to robbery and developed into adultery by sleeping with the women who were serving at the tabernacle. It is said that they debased the holy place (1 Sam. 2:13-17).

\section{(iii) Reminder/Prophetic Intervention}

Since their sins were incurable a number of prophetic interventions were indispensable. The first reminder was provided by their father Eli, the priest (1 Sam. 2:23-25). The second warning is given not only to

Traditions (Englewood Cliffs: Prentice-Hall, 1972): 74-75, 274. It is evident that the book of Numbers has a different theological view from DtrH. In Num. 16:22 Moses and Aaron say, 'And they fell on their faces, and said, 'O God, the God of the spirits of all flesh, shall one man sin, and will you be angry with all the congregation?' In addition, we can discover a different theology in Gen. 18:23. Abraham says, 'Then Abraham drew near, and said, "Will you indeed destroy the righteous with the wicked?" Thus these passages show that this DtrH theology is distinct from others.

18 I focused mainly on the punishment narratives discovered in Samuel-Kings. Achan's narrative is another possible example which appears outside of Samuel-Kings (Josh. 7:1-26). 
the sons but to all the family by the mouth of an anonymous prophet (1 Sam. 2:27-36). He reminds them of their election to the priesthood. It combines well with Deuteronomistic theology which attributes the responsibility to the head of a family or nation. The sins were committed by his sons but the responsibility is given to Eli, the head of the people, like Manasseh. ${ }^{19}$ The last reminder is proclaimed by Samuel (1 Sam. 3:11-14). It is remarkable that the same phraseology, 'the two

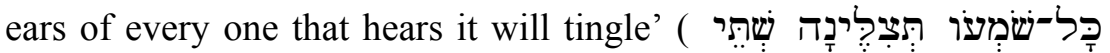
אָזָזָזיר narrative at the beginning and the conclusion of Samuel-Kings. Thereby the Eli and Manasseh narratives are paralleled with each other in language and narrative schemes. ${ }^{20}$ This intervention re-emphasises the election of the family and the importance of the chosen place:

a. Yahweh specially chose their family from all of Israel (v. 28).

b. They defiled the holy place (v. 29).

c. They can continue only when they obey him (v. 30).

Then it describes what would be the reward for cheating (1 Sam. 2:2329). These three prophetic judgements (1 Sam. 2:23-25; 27-36; 3:1214) are integrated into one judgement. But they are only split to increase the dramatic effect of the narrative adding to the weight of the punishment. It indicates that they had been rebuked many times.

\section{(iv) Response/Climax}

Eli's family did not listen to the warnings:

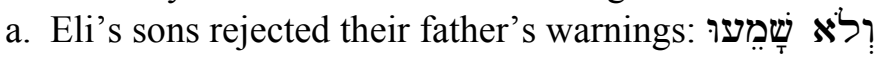

b. Eli also rejected the prophetic warnings (1 Sam. 2:25; 3:1-10).

\section{(v) Punishment}

The judgement says that the sins of Eli's family never can be atoned for by sacrifice or offering (1 Sam. 3:14). The Deity is determined to destroy them. The fulfilment is accomplished as follows.

a. Eli's sons and Eli were killed in war (1 Sam. 4:11). Eli died when he heard the bad news $(4: 18) .{ }^{21}$

19 Lasine rightly pointed out that the sin of Manasseh represents that of the whole nation. Lasine, 'Manasseh as Villain and Scapegoat', 163-183.

20 I discuss this issue later in more detail.

21 The importance of the punishment of Eli was in the mind of the Dtr. He mentions

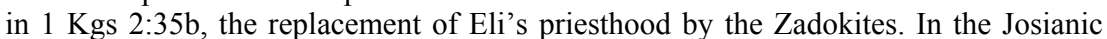
reform the author mentions 'the priests of the high places' to the Jerusalem priesthood (2 Kgs 23:9). Eli's family reign - he was a cultic and political ruler of the nation at that time - was legitimately ended by the punishment. 
b. Yahweh's glory disappeared. The ark was captured by the Philistines and the temple place devastated. (1 Sam. 4:11).

c. Eli's daughter-in-law, Phinehas' wife died in labour crying, אי כבוד , 'the glory has departed from Israel'. She announces the ending of one period with the departure of the glory of God. In a strict sense she and her baby were the only just ones in Eli's family (1 Sam. 4:19-22). ${ }^{22}$ She died and the unfortunate innocent baby was named by his mother symbolising the fate of the family and nation.

\subsection{Saul's Punishment (1 Sam. 12:1-31:6): First Opponent of Judah}

A more complicated punishment narrative appears in the account of Saul. His narrative is relatively long, ranging from 1 Samuel 22 to 1 Samuel 31 because it is intertwined with David's narrative. Its complexity also arises from the author's aim to preserve some important traditions about David's succession. Thus it is not so easy to single out the punishment narrative factors. Yet the core elements which constitute Saul's punishment narrative can be similarly detected. His punishment narrative begins at 1 Samuel 13 and ends in 1 Samuel $31: 13$. It also contains remarkable similarities with and allusions to Jeroboam's punishment narrative.

\section{(i) Sin Description}

Samuel told Saul to wait seven days until he arrived before sacrificing. It is strange that this commandment was given before he became king (1 Sam. 10:8). It is likely that Saul had already forgotten this cultic order when he violated this taboo (1 Sam. 13:8-14).

\section{(ii) Sin Development}

This tragic king persistently sinned until he died in battle. Sadly he had continued this cultic disobedience. Saul committed a further sin by sparing Agag the Amalekite king. He also took the best animals which should have been annihilated (1 Sam. 15:9). He went to En Dor to consult a woman medium (1 Sam. 28:7-15).

\section{(iii) Reminder/Prophetic Intervention}

He was repeatedly warned about his misdeeds. The first accusation appears in 1 Samuel 13:13-14 when he made a burnt offering. The second was given when Saul defiled the regulation of a holy war.

22 See other examples: 1 Sam. 31:2; 1 Kgs 14:18; 2 Kgs 24:29. 
Samuel reminded him of God's election (1 Sam. 15:17) and his rejection of the word of the Lord (v. 23). He coldly announced that the Lord had already given his kingdom to his neighbour (v. 28). Then Saul met Samuel's spirit and it forecast his final disaster. He and his sons would be killed in battle (1 Sam. 28:19).

\section{(iv) Response/Climax}

Samuel accused Saul of not listening to the Lord's voice (15:17-23). But he paid heed to the request of a female medium (1 Sam. 28).

(v) Punishment (28:16-19) 23

a. He was killed in war

b. His innocent son Jonathan and other sons were killed with him on the battle field (31:1-6). ${ }^{24}$

c. The first rival dynasty of Judah is devastated by his death. ${ }^{25}$

d. Saul's body was abandoned and ridiculed by a pagan cult (31:9).

\subsection{Jeroboam's Punishment: the Second Opponent of Judah}

\section{(i) Sin Description}

Jeroboam's narrative begins with his character description (1 Kgs 11:26-28). The prophet Ahijah plays an important role in the narrative to establish the northern kingdom. He delivers a message from Yahweh to anoint Jeroboam as king and announces his punishment.

\section{(ii) Sin Development (1 Kgs 12:25-13:1-5)}

Jeroboam built two golden calves in Bethel and Dan (1 Kgs 12:28-30). He also set up high places and hired common people to work as priests (v. 31). He did not stop there but he accumulated his sins by conducting burnt offerings by himself (v. 33). His misconduct was

23 Saul's punishment was only about the rescission of his leadership at first (1 Sam. 13:13-14). But when his repeated disobedience overstepped the mark the Deity inflicted more serious punishment on him.

24 Be careful with the description in 1 Sam. 28:18-19. The Deity poured out his anger not only on Saul but also on his sons because of Saul's trangression.

25 When we think of the punishment of Saul, the proper ending of the Saul narrative seems to be at 1 Sam. 30:13. Therefore the Ishbosheth narrative (2 Sam. 2:8-4:12) coming afterward looks odd. However, this is not strange as we consider the double accounts of the destruction of Judah (Jehoiachin and Zedekiah). This addition came from Dtr's style in dealing with historical materials. It was necessary for him to mention the Ishbosheth material to emphasise the legitimate end of Saul's dynasty. So David's legitimate dynasty began with the congregation of all the tribes asking for David to be their king in 2 Sam. 5:1. 
interrupted by a prophet from Judah with a severe warning and a sign (1 Kgs 13:2). Instead he increased his sins leading up to his baby dying because of his sins. It was a sign of the fulfilment of the punishment. But he remained a wicked man who never repented (1 Kgs 14:16-18).

(iii) Reminder/Prophetic Intervention (13:2-3)

When Jeroboam made burnt offerings a prophet came from Judah and announced that the priests of the high places and men's bones would be burned by Josiah (1 Kgs 13:2-3). Even the old prophet who buried the prophet of Judah confirmed the announcement of the prophet $(1 \mathrm{Kgs}$ 13:33). ${ }^{26}$ The Deity used many prophetic voices to call him to repentance (1 Kgs 17:22).

(iv) Response/Climax (1 Kgs 13:4-6, 33)

$\mathrm{He}$ responded by attempting to kill the prophet. Even after the miraculous paralysing of his one hand and the experience of healing he never showed any change of heart (1 Kgs 13:4-6). In $1 \mathrm{Kgs}$ 13:33 it says, 'after this thing Jeroboam did not turn from his evil way'. The useful terminology repeating the word שוב is also applied here again.

\section{(v) Punishment (1 Kgs 14:7-16)}

Jeroboam's was the first northern dynasty. In a strict sense he is nothing to do with Omri or king Hosea either. However, Dtr connected the fall of Israel with the sin of Jeroboam ( $2 \mathrm{Kgs} \mathrm{17:22).} \mathrm{In} \mathrm{addition,}$ the wording used for the accusation of Jeroboam is remarkably similar to the Manasseh narrative. It says, 'the people of Israel walked in all the sins that Jeroboam did. They did not depart from them, until the LORD removed Israel out of his sight, as he had spoken by all his servants the prophets' (2 Kgs 17:22). As for Manasseh, the Deity used many prophets to turn Israel away from their evil deeds. Dtr depicts the beginning of his punishment as the death of an innocent baby. It is surprising that Dtr says that the baby was the only one who had the right attitude in his heart. Sadly, the baby died on account of his father's sin. Thus it is evident that the baby's death reflects the death of Josiah as well. The second fulfilment of the punishment is

26 For a defence of the unity of $1 \mathrm{Kgs}$ 12:33-13:33 by J. van Seters contra Knoppers, McKenzie, and A Rofé see John Van Seters, 'The Deuteronomistic History: Can It Avoid Death by Redaction?' in Future of the Deuteronomistic History (Leuven: Peeters, 2000): 213-22. However, his estimation of the date of the composition (he sees that it is not earlier than the late Persian or early Hellenistic periods) is still debatable. 
accomplished in the death of Jeroboam's son Nadab (1 Kgs 15:28-30). It explains that Baasha killed all the house of Jeroboam. It must be the fulfilment of the prophecy given by Ahijah the Shilonite. It is not strange that the writer wanted to connect Jeroboam's name with the fall of Israel. I think that this is a very intentional device to exhibit the Deuteronomistic theology.

\subsection{Allusion to Saul and Jeroboam}

P. Buis contends for some similarities between 1 Samuel 2:27-36 and $1 \mathrm{Kgs}$ 14:7-16.27 However, considerable similarity can be detected between Saul's and Jeroboam's punishment narratives. Interestingly Saul's and Jeroboam's narratives did not use the direct wording used in Eli's and Manasseh's narratives. ${ }^{28}$ Instead, they use remarkable allusions to imply each other.

\section{(i) Prophecy}

a. Saul did not eat anything before he met a woman medium (1 Sam. 28:20). A prophet from Judah was commanded not to eat anything (1 Kgs 13:8).

b. Saul first rejected the food provided by a sorceress. Then he accepted the offer before he was killed (1 Sam. 28:22-23, 25). The prophet rejected Jeroboam's food but finally accepted an old prophet's offer before he was killed (1 Kgs 13:9, 17-19)

c. A dead prophet's spirit announced Saul's end (1 Sam. 28:15-19). The prophet to be killed announced Jeroboam's end (1 Kgs 13:3).

d. Saul was killed and buried under a tree (1 Sam. 31:13). The prophet sat under a tree when he met a son of an old prophet who lived in Bethel (1 Kgs 13:14).

e. Saul was killed and his body was abandoned (1 Sam. 31:8-13). The prophet was killed and his body was abandoned (1 Kgs 13:24).

f. The people of Jabesh-gilead buried Saul's body and mourned for him (1 Sam. 31:13). An old prophet buried the prophet's body and mourned for him (1 Kgs 13:29-30).

27 Pierre Buis, 'Notification de jugement et confession nationale', BZ 11 (1967): 193205. Cf. Richard Nelson, 'The Role of the Priesthood in the Deuteronomistic History' in Congress Volume: Leuven 1989 (VT Sup 43; Leiden: E. J. Brill, 1991): 139-40.

28 'I am bringing a calamity upon Jerusalem and Judah, that whoever hears of it, both his ears will tingle' (2 Kgs 21:12). Compare it with 1 Sam. 3:11. 
(ii) Kingship

a. Saul was a mighty man (גבור חיל) in his appearance (1 Sam. 9:1). Jeroboam was also a mighty man (גבור חיל) (1 Kgs 11:28).

b. Saul was not a proper king but a concession before the call of a Judahite king (1 Sam. 8:4-22; 12:12-18). Jeroboam was not a proper king but a concession because of the sin of Judahite king Solomon (1 Kgs 11:11-13, 32-36).

c. Samuel's torn garment became a sign that Yahweh would tear his kingdom and give it to David (1 Sam. 15:27). Jeroboam took ten pieces of Ahijah's garment as a sign that Yahweh would give the ten tribes to him (1 Kgs 11:30).

d. All Israel was gathered to see Saul when he became king (1 Sam. 11:14-12:25). All Israel was gathered to set up Jeroboam as their king (1 Kgs 12:1-20).

e. Samuel was a prophet to make Saul king of Israel (1 Sam. 12). He also announced the destruction of Saul's dynasty. The prophet Ahijah was important in setting up Jeroboam as king and he announced the destruction of Jeroboam's dynasty (1 Kgs 11:29-39; $14: 7-16) .{ }^{29}$

\subsection{Manasseh's Punishment: The Destruction of the Last National Cultic Place and the Fall of Judah}

When we return to the Manasseh narrative the same patterns can be detected there. It is presumed that the Manasseh narrative in $2 \mathrm{Kgs}$ 21:1-18 belongs to a whole range of punishment narratives which ends in $2 \mathrm{Kgs} 24: 17 .{ }^{30}$

\section{(i) Sin Description}

The narrative begins with Manasseh's character evaluation (2 Kgs 21:2) and the general list of his sins (v. 3). He nullified his father Hezekiah's reforms (v. 3a). He reconstructed the high places and contaminated Yahweh's sacrifice with pagan worship (v. 3b).

29 The prophet Shemaiah also appears to announce the confirmation of the northern kingdom (1 Kgs 12:22-24).

30 The importance of the relationship between the accounts of Manasseh and Josiah has been indicated by Smelik and Eynikel. K. A. D. Smelik, Converting the Past: Studies in Ancient Israelite and Moabite Historiography (Leiden/New York: E.J. Brill, 1992): 154; Eynikel, 'The Portrait of Manasseh and the Deuteronomistic History', 234. 


\section{(ii) Sin Development}

His sins are described in detail from verses 4-8. He defiled the chosen place by setting up the Asherah pole and altars to all the starry hosts committing sorcery as well (vv. 4-7a). ${ }^{31}$ Manasseh's sins became worse by polluting the temple surroundings by practising sorcery and divination and setting up the Asherah pole in the temple itself (v. 7). However, in spite of the reminder, Manasseh aggravated his sins by killing many innocent people (v. 16).

\section{(iii) Reminder/Prophetic Intervention}

The reminder of judgement by prophetic intervention against the sins of Manasseh was provided by two indirect and direct prophetic speeches. He was warned by a reminder of the covenant in indirect speech in vv. 7-8. The Deity rebuked him by reminding him of the relationship between faith and the covenant given to David and Solomon.

a. Yahweh had specially chosen their family from all the tribes of Israel (v. 7b)

b. Yahweh chose the place to put his name (v. 7b)

c. The Davidic covenant is effective only when the Israelites obey the law given by Moses (v. 8).

The Davidic and Mosaic covenants are not separated from each other but are closely related. This reminder is not given by the direct voice of a prophet but indirectly by the narrator. But he quotes with a direct voice in the passage: 'I have chosen out of all the tribes of Israel, I will put my name forever' (v. 7b). Here he gives a reminder of the importance of the chosen place where God's name remains forever.

Finally the prophetic judgement was delivered in a direct voice 'I am going to bring a disaster on Jerusalem and Judah that the ears of everyone who hears of it will tingle' (vv. 10-15). Thus the decision of Yahweh to destroy Jerusalem and Judah is inevitable. The discourse sequence of the reminder of the covenants (vv. 7b-8) and the prophetic judgement (vv. 10-15) are interrupted by v. 9 (response). But in the process of the story their time and function overlap each other. ${ }^{32}$ They

31 In function, v. 3 introduces Manasseh's evil deeds at a glance while vv. 4-8 qualify the behaviour by mentioning the law, the covenant, and the cultic place.

32 According to Chatman, the story is the abstract content in the writer's head while the discourse is the tangible presentation of the story. For the relation between story and discourse, see Seymour Benjamin Chatman, Story and Discourse: Narrative Structure in Fiction and Film (Ithaca: Cornell University Press, 1980): 277. 
are only split for the purpose of discourse presentation. In other words, the prophetic rebuke ( $\mathrm{vv} .10-15)$ premises the listener's knowledge of the content in vv. 7-8.

\section{(iv) Response/Climax}

The response of Manasseh and the people is presented in verse 9. Not only Manasseh, but all the nation responded by rejecting the prophetic reminder. These warnings had been given by many voices: יחוֹ

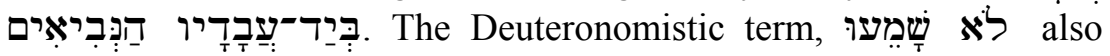
occurs here.

\section{(v) Punishment}

The due punishment is to be fulfilled in several ways. The first signal of the fulfilment of the punishment is presented by the death of Josiah. The second was presented by the military defeat (14:1-4). The last was fulfilled by another military defeat (24:10-12), the destruction of the cultic place (v. 13) and the deportation of the people (v. 14). The writer can speed up this process or slow it down, in order to enhance the effectiveness of the narrative. ${ }^{33}$ Judah's final punishment narrative ranges from Manasseh to Zedekiah (24:17). ${ }^{34}$ The author specially enhanced this latter part because it is also the finale of the book of Kings and the DtrH. Therefore, Josiah's narrative cannot be fully understood without Manasseh's part. The role of the women who are paralleled in the Eli and Manasseh narratives is also important. They have been employed as a prophetic announcement and echo. At the last scene in the fulfilment of the prophecy, Eli's daughter-in-law announces the fulfilment of the disaster. At the same time Huldah the prophetess also announces the fate of Judah. And this kind of woman's voice does not reappear before the culmination of the destruction. So

33 Mary E. Mills, 'Historical Israel, Biblical Israel: Joshua to 2 Kings', 65. See also Shimon Bar-Efrat, Narrative Art in the Bible (Sheffield: Almond, 1989): 280.

34 It is also problematic when the punishment for the sin of Manasseh actually ended. The book of Kings depicts two kinds of devastation of Jerusalem, in the times of Jehoiachin and Zedekiah. However, I think that the Dtr had two different kinds of destruction materials/traditions. So he intended not to choose either one of them. But he imposed some theological meaning on each incident. He thought that the punishment for the sins of Manasseh had been fulfilled until $2 \mathrm{Kgs}$ 24:17. To the Dtr the disaster in $2 \mathrm{Kgs} 25$ is an additional punishment for the continuous offences. The people of Judah saw the punishment as being fulfilled in their history. But they still refused to return from their sin. We can even find a seam between the two different materials about the fall of Judah. The Dtr tried to demonstrate his coherent message weaving different materials into one narrative thread. 
previous studies which examined the discrepancies only within each narrative perimeter, seeking for a breach in secondary accreditations, ${ }^{35}$ have limitations in the understanding of the comprehensive narrative stratagem of the Dtr. In order to comprehend the Manasseh narrative a reader should recognise the punishment narrative on a wider scale. Accordingly, Manasseh and Josiah's narratives are constituted as a complete punishment pericope.

\section{The Allocation of the Punishment Narratives in Samuel-Kings}

Not only do these narratives possess similar patterns but they also overarch in Samuel-Kings by paralleling one another. Eli's punishment narrative is parallel with Manasseh's whereas Saul's narrative is paired with Jeroboam's. Saul and Jeroboam were both rivals to the Southern kingdom: Saul was a rival of David and Jeroboam was of Rehoboam. Eli's narrative is located at the prelude, alluding to the national disaster whereas Manasseh's narrative is situated at the conclusion portraying the condemnation and the punishment of the last kingdom. Thus Eli's and Manasseh's punishment narratives form an inclusio of the whole structure of Samuel-Kings. When we read the two different stories of Eli and Manasseh's punishment narratives we can observe some intriguing similarities. Thus the author uses Eli's story as an introduction to the book of Samuel-Kings and concludes with the story of Manasseh looking back to the beginning of the whole account. It is certain that there is an intention to start a new unit from the Eli episode.

35 Cross, Canaanite Myth and Hebrew Epic, 376; John Gray, I \& II Kings (London: SCM Press, 1964): 706-709; Richard D. Nelson, The Double Redaction of the Deuteronomistic History (Sheffield: JSOT, 1981): 65-68. For a summary of a number of different literary critical positions of the Manasseh text see Burke O. Long, 2 Kings (FOTL 10; Grand Rapids: Eerdmans, 1991): 247; M. A. O'Brien, The Deuteronomistic Hypothesis: A Reassessment (OBO 92; Göttingen: Vandenhoeck \& Ruprecht, 1989): 227-34, especially n. 1. Erik Eynikel, 'The Portrait of Manasseh and the Deuteronomistic History' in Deuteronomy and Deuteronomic Literature, ed. M. Vervenne (Leuven: Peeters, 1997): 233-66. Recently Sweeney claimed that 'the report of YHwh's decision to destroy Jerusalem and Judah in vv. 10-15 does not constitute the centrepiece of the Manasseh narrative; rather it interrupts the evaluation of his reign'. Thus he considers the possibility of secondary insertion of vv. 10-15 between vv. 2-9 and 16. Marvin A. Sweeney, King Josiah of Judah: The Lost Messiah of Israel (Oxford: Oxford University Press, 2001): 56. But his observation is uncertain because v. $2 \mathrm{~b}$ and v. 8 allude to the punishment and the destruction of Judah. 
Noth contends that the time of the Judges ends in 1 Samuel 12.36 However, I think the period actually ends with the statement of 1 Samuel 4:21. 1 Samuel 4:18 also indirectly presents a Deuteronomistic announcement that the period ended with the fortieth year of Eli's reign. The Dtr chose Eli's family as the subject of the tragic ending. Meanwhile he used Samuel as a mediator between the time of the Judges and the monarchic period. From the beginning of the book of Samuel the author foreshadows the fall of Judah in comparing the destruction of the first cultic location and the Jerusalem temple. These punishment narratives cover the whole monarchic period describing punishment and destruction. ${ }^{37}$ Josiah's reform and his death show that judgement is inevitable. The faithful reform of Josiah could not save the nation from disaster but shows how serious their sins had been $(2$ Kgs 22:15-29; 23:26-27). Thus the long account of Josiah's reform does not seem to depict the idealistic Davidic kingship because of its tragic ending. ${ }^{38}$

The importance of the 'promise-fulfilment' scheme has been rightly pointed out by Weippert. ${ }^{39} \mathrm{I}$ have shown that this concept prevails in Samuel-Kings by the prophetic interventions and operates as a significant factor in the punishment narratives throughout SamuelKings. In all these narratives the author is already portending the doom of Judah with catastrophic allusions. It seems that the author of Samuel-Kings had a tremendous interest in the destruction of the first cultus locus as an adumbration of the fate of Jerusalem. He employed

\footnotetext{
36 Martin Noth, The Deuteronomistic History (Sheffield: JSOT Press, 1981): 42.

37 His constant interest in Israel's history from Judges to Kings is mentioned in $2 \mathrm{Kgs}$ 23:22.

38 M. Sweeney contends that the DtrH writer was motivated by the king Josiah as an idealistic king like David while Manasseh was a foil to the opposite character of Josiah. Sweeney, King Josiah of Judah: The Lost Messiah of Israel, 350. However, my investigation of the narrative schemes adopted by the DtrH writer reveals that Manasseh was not a foil but an important pair character with Josiah.

39 She indicates more than sixty occurrences of the 'promise-fulfilment' scheme as the DtrH author's device. She also claims that it has been deeply embedded in the Dtr version and the redactors perceived this skill and utilised it in their composition. Helga Weippert, 'Geschichten und Geschichte: Verheissung und Erfüllung im deuteronomistischen Geschichtswerk' in Congress Volume: Leuven 1989 (VT Sup 43; Leiden: E. J. Brill, 1991): 117, 131. This feature has been the opinio communis of scholars as indicated early on by von Rad ('The Problem of the Hexateuch and Other Essays', 208-214).
} 
leading historical figures to manifest his theology at every crucial stage of Israel's history in the form of the punishment narratives. 